\title{
Effect of Pleurotus ostreatus White-rot fungi on Chemical Properties of Beech (Fagus orientalis) Wood Chips
}

\author{
*Saim ATEŞ ${ }^{1}$, Damla Didem AKYILDIZ ${ }^{1}$, Çağrı OLGUN ${ }^{1}$ \\ ${ }^{1}$ Kastamonu University, Faculty of Forestry, Department of Forest Industrial Engineering, Kastamonu \\ *Corresponding Author: saimates@kastamonu.edu.tr
}

Geliș Tarihi:06.10.2015

\begin{abstract}
Defibration is one of the most energy spent stage in pulp and fiberboard production. Today's different methods are available for reducing energy needs at this stage. Fungi usage is an important method for this purpose in recent decades. In this study, beech chips (Fagus orientalis), which is the most widely used in the Turkish fiberboard industry, are pretreated with edible Pleurotus ostreatus white rot fungi and investigated the effects of the chemical content of the chips. Consequently, totally $7727.6 \mathrm{gr}$ P. ostreatus mushroom is obtained and the lignin content of wood chips is dramatically decreased day by day. It was observed that lignin content of wood chips decreased by $22.03 \%$ at 72 th day after starting of fungi to emerge. Accordingly this results, it will be potentially saved the mechanical fibrillation energy, because dissolving the desired amount of lignin during fiberizing is reduced.

Key Words: Mushroom production, Beech chips, White rot fungus (Pleurotus ostreatus), Chemical components of wood
\end{abstract}

\section{Pleurotus ostreatus Beyaz Çürüklük Mantarının Kayın (Fagus orientalis) Yongalarının Kimyasal Özellikleri Üzerine Etkisi}

\begin{abstract}
Özet
Liflendirme kağıt hamuru ve liflevha üretiminin en çok enerji harcanan aşamalarından biridir. Günümüzde bu aşamadaki enerji ihtiyaçlarını azaltmak amaçlı farklı metotlar mevcuttur. Mantarların bu amaçla kullanımı son yıllarda ön plana çıkan önemli bir metottur. Bu çalışmada Türk liflevha endüstrisi için oldukça yaygın kullanılan bir tür olan kayın (Fagus orientalis) yongaları liflendirme öncesinde yenilebilir bir tür olan Pleurotus ostreatus beyaz çürüklük mantarı ile ön işleme tabi tutulmuş ve yongaların kimyasal içeriğine olan etkileri araştırılmıştır. Çalışma sonunda toplamda 7727.6 gr $P$. ostreatus mantarı üretilmiştir. Deneyler sırasında mantarların çıkmaya başlamasından sonra 12 gün ara ile alınan örneklerin lignin içeriklerinde sürekli bir azalma gözlemlenmiştir. İlk mantarın çıkmasından 72 gün sonra lignin miktarı \% 22.03 oranında azalmıştır. Buna göre liflendirme sırasında çözülmesi istenilen lignin miktarı azaldığından potansiyel olarak özellikle mekanik liflendirmede kullanılacak liflendirme enerjisinden tasarruf sağlanacaktır.

Anahtar Kelimeler: Mantar üretimi, Kayın yongaları, beyaz çürüklük mantarı (Pleurotus ostreatus), odunun kimyasal bileşenleri
\end{abstract}

\section{Introduction:}

Wood fibers derived from wood raw material are used in the production of paper and fiberboard (Eroğlu and Usta, 2000). Fiber production from wood raw material is possible by softening or lignin removal in the cell walls with combinations of mechanical energy, chemicals and temperatures (Kirc1, 2000). Especially medium density fiberboard (MDF) is one of the famous wood composite materials for various using areas. Generally MDF's are produce from wood fiber obtained by thermo-mechanical pulping (TMP) methods because of high yield and low energy cost then other pulping methods (Hua et al., 2012). But nowadays, TMP process requires considerable energy cost during the fiber production with increasing energy price (Singh et al., 2010).

Some methods are investigated to reduce of energy consumption in fiber production by mechanical energy. First of all it's called by chemical thermo-mechanical pulping (CTMP). In this process, some chemicals, which assist softening of wood chips, are sprayed onto chips in TMP process. However the energy consumption is reduced, the chemicals are increasing cost of the fiber production (Singh et al., 2010).

Wood is a natural renewable material and it is a source of food for some creatures. Researches on the basis of this property has focused some fungi species which are decrease lignin in the wood cell wall. These 
species usually degrade firstly lignin and later hemicellulose and cellulose. After the lignin degradation of wood, wood's color is bleached. Therefore these fungi are named as white rot fungi (Nilsson, 2009).

The treatment of wood chips by white-rot fungi has mainly studied for paper production and named biopulping. According the most research on this area, biopulping improve the quality of mechanical pulps and significantly reduce the energy consumption (Singh et al., 2010). Myers et al. (1988) studied the effects of two white-rot fungi, which are Phanerochaete chrysosporium and Dichomitus squalens, on aspen chips for mechanical pulping. According the study results, lignin content of samples was reduced by fungal treatment. Particularly $D$. squalens pretreatment significantly affected fiber distribution and reduced fines content of obtained mechanical pulp. In the other research, Loblolly pine was pretreated with Ceriporiopsis subvermispora white rot fungus. After four weeks, weight loss of chips ranged from $4 \quad-7 \%$ electrical consumption of fiber production decreased to 21-37\% and burst and tear indices of paper samples, which are made from all fungal pretreated fiber, improved (Akhtar et al., 1992). When the aspen woods were pretreated with $C$. subvermispora, the energy consumption of refining decreased $40-48 \%$, burst, tear and tensile strength of paper samples were improved (Aktar, 1994).

Akhtar et al. (2000) were tried to industrial level biomechanical pulping by 50 tons spruce wood chips treated with white rot fungus $C$. subvermispora. They reported that after treated chips stored in outdoor chip pile 2 weeks, fiber production energy consumption was decreased $33 \%$ ratio and paper strength properties significantly improved according to control.

Changes in the amount of Uludag fir (Abies bornmülleriana) and beech (Fagus orientalis) wood chemical components by the $P$. chrysosporium treatment were determined. It was reported that holocellulose and lignin ratios of both wood type decreased when cellulose ratio and solubility values increased (Istek et al., 2005).
Kang et al. (2007) were treated pine (Pinus densiflora) and poplar (Populus alba x grandulosa) with three white rot fungi $P$. chrysosporium, Trametes versicolor and $C$. subvermispora. They determined relationship between fungal activity and wood degrading capacities of white rot fungus with wood decay test and chemical analyses during the 60 days. They reported that large amount of lignin in woods degraded at early stage and $P$. chrysosporium showed the best capability than other test fungus.

Mechanical and chemical properties of pretreated beech heartwood and sapwood by Coriolus versicolor were tested. It was reported that heartwood of the beech wood was founded more durable than sapwood samples for this fungi according the test results (Malakani et al., 2014).

Turkish fiberboard industry was the world's 3rd largest industry according to data from year 2012 and developing day by day (Akgül et al. 2013). Turkish fiberboard industry need more energy with this developing and literature studies (Akhtar et al. 1992; Akhtar, 1994; Scot et al. 1988; Akhtar et al. 1999; Akhtar et al. 2000; Ferraz et al. 2008) showed that fungal treatment for mechanical pulping can be saved approximately $30 \%$ energy consumption. For this reason the importance of white rot fungi using in mechanical fiber production increases for Turkish fiberboard industry. Besides this, nowadays many region of world have famine problem. Thus increasing production of edible fungus will be help for the solution of this problem. A type of edible mushroom Pleurotus ostreatus Jacq. is a species of white rot fungi, which is inhabitant on various broad-leaved tree species, such as beech, poplar, alder, and aesculus (Unal et al., 2012). Especially beech is used quite a lot in Turkish fiberboard industry. For this reason, $P$. ostreatus has a great potential for biomechanical pulping in Turkey.

The aim of this study is to focus on determining of the amount of eatable mushroom at different culturating times, and at the same time, determining the changes of chemical content of beech wood chips treated by $P$. ostreatus fungi. 
Material and Methods

\section{Production of Pleurotus ostreatus}

Beech (Fagus orientalis) lumbers, obtained from Kastamonu province in the Western Black Sea region of Turkey. Wood samples were cut into wheels, approximately $2 \mathrm{~cm}$ height, and dried. After that, chips, 2 $\mathrm{mm}$ thick and $1.5-2 \mathrm{~cm}$ high, were obtained from the wheels. A part of chips were saved as a control sample and others were sterilized for the purpose of prevent the growth of other organisms. Sterilized chips were divided into 6 groups and each group was 4 $\mathrm{kg}$. P. ostreatus micelles, produced in the laboratory at $20 \pm 2 \mathrm{~g}$ and $60 \pm 2 \mathrm{~g}$ from stock, were inoculated for each group. Samples were climatized on $27 \pm 2{ }^{\circ} \mathrm{C}$ and
$70 \pm 5 \%$ RH for a period of 15 days. After the climatized, samples are shocked $\left(4-5^{\circ} \mathrm{C}\right.$ for 2 days), they are set to a special cabinet (room conditions and indirect lighten 24 hour a day). Finally, treated chips dried on $40 \pm 2$ degrees 3 days and mushroom production was terminated after the occurring of the first fungi every $12^{\text {th }}$ days $(12,24,36,48,60,72$ days).

\section{Determination of chemical components}

Treated and control samples were milled (particle size between 0.05 and $0.4 \mathrm{~mm}$ ) and were stored in closed glass jars at room temperature until analysis. Standard test methods are used for determination of chemical components (Table 1).

Table1 The standards used in determining the values of $P$. ostreatus treated beech chips

\begin{tabular}{ll}
\hline Experiments & Standards \\
\hline Alcohol-benzene soluble (\%) & TAPPI T 204 om-88 (TAPPI, 1988 a) \\
Hot and cold water soluble (\%) & TAPPI T 207 om-93 (TAPPI, 1993 a) \\
$1 \%$ NaOH soluble (\%) & TAPPI T 212 om-93 (TAPPI, 1993b ) \\
Holocellulose content (\%) & Chlorite method (Wise et al. 1946) \\
Alpha cellulose content (\%) & TAPPI T 203 om-93 (TAPPI 1993 c) \\
Lignin content (\%) & TAPPI T 222 om-88 (TAPPI, 1988 b) \\
Ash content $(\%)$ & TAPPI T 413 om-93 (TAPPI, 1993 d) \\
\hline
\end{tabular}

\section{Results and Discussion}

Amount of mushroom production on periods is shown in Table 2. After the production of mushroom, changes in beech wood components and solubility values relative to control sample are given in Table 3. Approximately 400 gr mushroom was obtained from all groups in first period. The yield decreased with increasing the time. The main reason of this is high lignin content reduction in the treated chips according the Table 3 and Figure 1. Totally yield of mushroom in first period nearly $10 \%$ and approximately $2 \mathrm{~kg}$ yield was harvest from the $4 \mathrm{~kg}$ beech chips according the 6th group results.

Table 2. Amounts of the fungi produced on periods (gr)

\begin{tabular}{|c|c|c|c|c|c|c|c|}
\hline \multirow{2}{*}{$\begin{array}{l}\text { Time } \\
\text { (day) }\end{array}$} & \multicolumn{6}{|c|}{ Groups } & \multirow{2}{*}{ Total } \\
\hline & 1. group & 2. group & 3. group & 4. group & 5. group & 6. group & \\
\hline 12 & 485.5 & 441.4 & 393.3 & 467.8 & 439.8 & 317.9 & 2545.7 \\
\hline 24 & --- & 405.6 & 410.9 & 400.4 & 396.2 & 386.8 & 1999.9 \\
\hline 36 & & --- & 390.7 & 375.7 & 390.2 & 380.7 & 1537.3 \\
\hline 48 & & & --- & 253.5 & 304.7 & 315.4 & 873.6 \\
\hline 60 & & & & --- & 245.3 & 267.2 & 512.5 \\
\hline 72 & & & & & --- & 258.6 & 258.6 \\
\hline Total & 485.5 & 847.0 & 1194.9 & 1497.4 & 1776.2 & 1926.6 & 7727.6 \\
\hline
\end{tabular}


Table 3. Changes in the amount of beech wood component with incubation periods

\begin{tabular}{|c|c|c|c|c|c|c|c|c|}
\hline \multirow[b]{2}{*}{$\begin{array}{l}\text { Time } \\
\text { (day) }\end{array}$} & \multicolumn{8}{|c|}{ Analyses (\%) } \\
\hline & $\begin{array}{c}\text { Lignin } \\
\text { Content }\end{array}$ & $\begin{array}{l}\text { Holocellulose } \\
\text { Content }\end{array}$ & $\begin{array}{l}\text { Alpha } \\
\text { cellulose } \\
\text { content }\end{array}$ & $\begin{array}{l}\text { Alcohol- } \\
\text { benzene } \\
\text { extraction }\end{array}$ & $\begin{array}{l}1 \% \mathrm{NaOH} \\
\text { solubility }\end{array}$ & $\begin{array}{c}\text { Cold water } \\
\text { solubility }\end{array}$ & $\begin{array}{l}\text { Hot water } \\
\text { solubility }\end{array}$ & Ash \\
\hline Control & $23.6 \pm 1.83^{*}$ & $73.0 \pm 0.19$ & $43.9 \pm 0.03$ & $2.92 \pm 0.00$ & $19.6 \pm 0.07$ & $3.50 \pm 0.00$ & $4.20 \pm 0.07$ & $0.42 \pm 0.03$ \\
\hline 12 & $20.9 \pm 0.19$ & $75.8 \pm 0.11$ & $44.6 \pm 0.01$ & $2.77 \pm 0.02$ & $20.2 \pm 0.14$ & $2.68 \pm 0.03$ & $3.40 \pm 0.00$ & $0.46 \pm 0.03$ \\
\hline 24 & $20.5 \pm 0.14$ & $76.3 \pm 0.22$ & $44.9 \pm 0.07$ & $2.62 \pm 0.14$ & $20.6 \pm 0.57$ & $3.13 \pm 0.10$ & $4.00 \pm 0.07$ & $0.51 \pm 0.00$ \\
\hline 36 & $20.1 \pm 0.99$ & $76.9 \pm 0.31$ & $45.4 \pm 0.11$ & $2.45 \pm 0.21$ & $21.0 \pm 0.07$ & $3.10 \pm 0.00$ & $4.33 \pm 0.18$ & $0.49 \pm 0.00$ \\
\hline 48 & $19.9 \pm 0.14$ & $77.1 \pm 0.20$ & $45.6 \pm 0.31$ & $2.37 \pm 0.02$ & $21.7 \pm 0.07$ & $2.90 \pm 0.07$ & $4.05 \pm 0.07$ & $0.59 \pm 0.00$ \\
\hline 60 & $18.8 \pm 0.14$ & $77.1 \pm 1.04$ & $45.6 \pm 0.13$ & $2.19 \pm 0.26$ & $22.0 \pm 0.35$ & $2.93 \pm 0.04$ & $4.63 \pm 0,11$ & $0.77 \pm 0.00$ \\
\hline 72 & $18.4 \pm 0.70$ & $77.5 \pm 0.11$ & $45.8 \pm 0.07$ & $2.05 \pm 0.12$ & $22.8 \pm 0.14$ & $3.18 \pm 0.18$ & $4.45 \pm 0.21$ & $0.62 \pm 0.03$ \\
\hline
\end{tabular}

* Standard deviation values

Lignin serves as an adhesive between the wood cells (Fengel and Wegener, 1989). Therefore this content is most important value for the defibration in fiber production. Figure 1 indicates in detail the lignin content change. The lignin content is decreased day by day. After the 72 days, average $22.03 \%$ of lignin is degraded by $P$. ostreatus fungus. Ferraz et al. (2008) were founded that lignin was rapidly decreased in first 30 days for $C$. subvermispora treated eucalyptus wood and it can be said that lignin degradation is same as for $P$. ostreatus treated beech wood chips. Fungal treatment for mechanical pulping can be saved approximately $30 \%$ energy consumption with reducing lignin content accordingly other studies (Akhtar et al., 1992; Akhtar et al., 1994; Akhtar et al., 1998; Akhtar et al., 2000). Therefore, P. ostreatus treatment can be used in wood fiber production as a method for reducing energy consumption.

In the Figure 2, it is clearly shown that holocellulose and alpha cellulose content are changed by time (Figure 2). However, these values has not changed at the same level according to the periods. Qualities of lignin can be shown as the reason for this situation. Because lignin is a highly amorphous polymer and has bonds between other components of wood cell wall (Fengel and Wegener, 1989). So, other polymers must be degraded while reducing lignin. In the Figure 2 , we can be showed that $P$. ostreatus treatment is fewer degraded holocellulose and alpha cellulose units when lignin is degraded. As a consequence, P. ostreatus treatment is useful for biomechanical pulping.

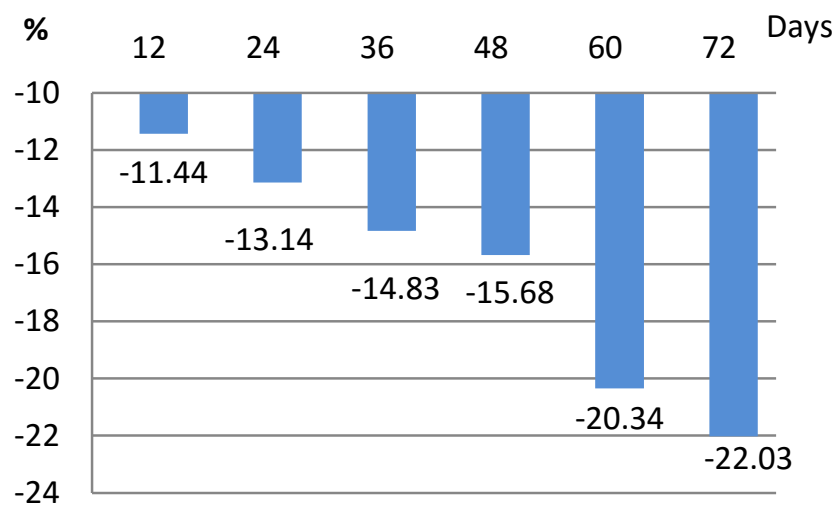

Figure 1 . The changes in lignin content by incubation time $(\%)$ 

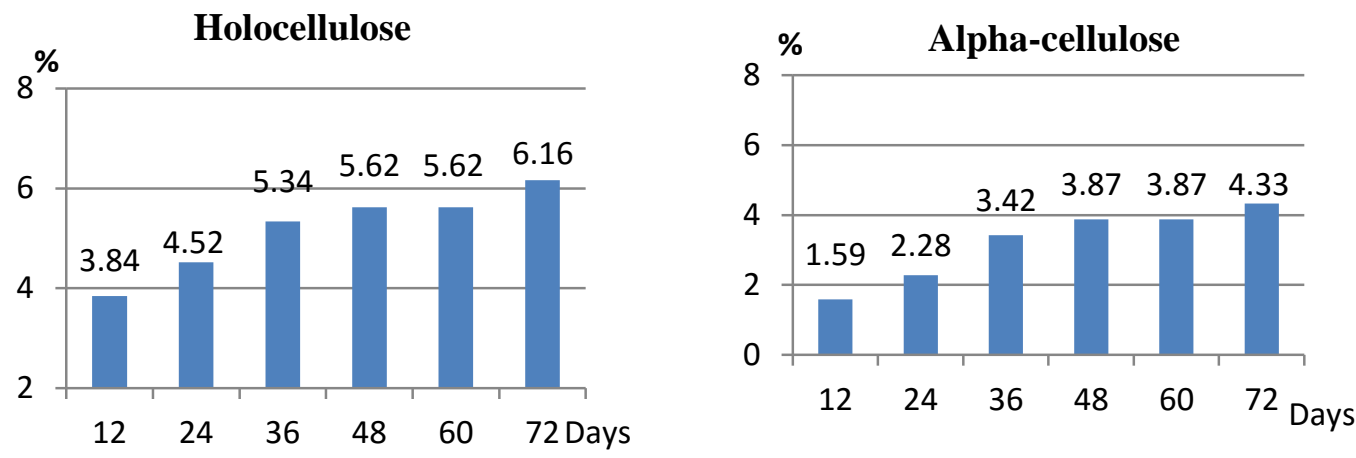

Figure 2. Amount of change ratio of holocellulose and alpha cellulose content (\%)

Hot water

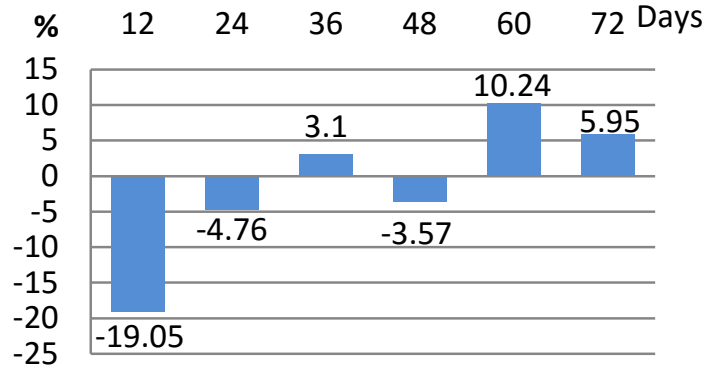

Alcohol-Benzene

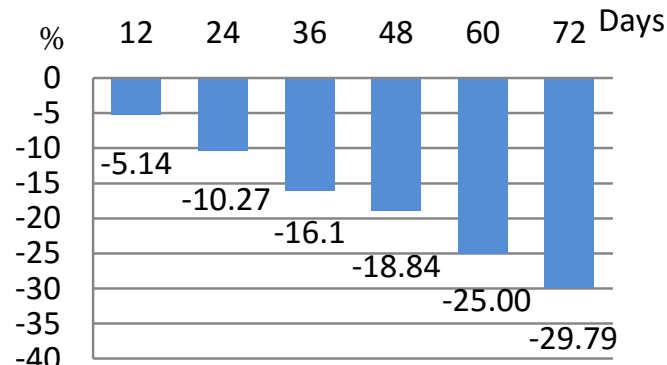

Cold water

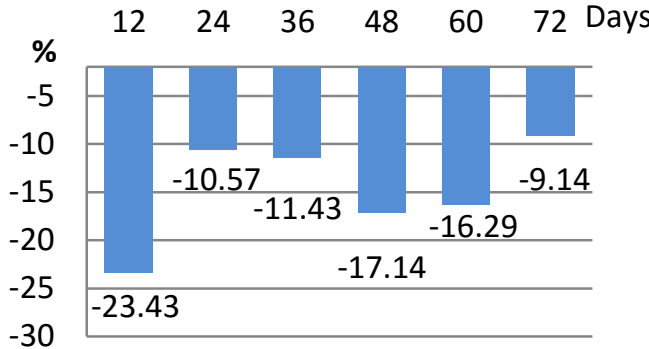

$1 \% \mathrm{NaOH}$

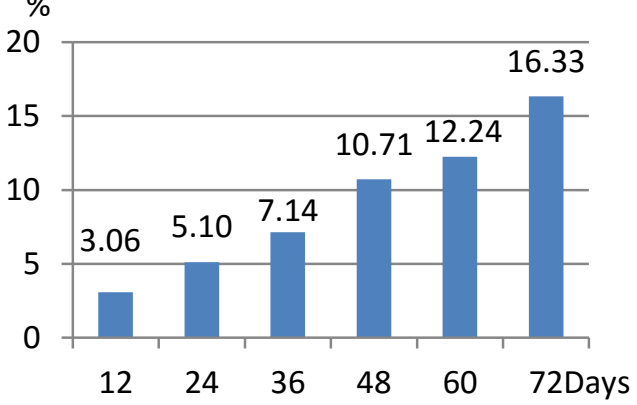

Figure 3. Changes in wood extractive and solubility values (\%)

In the Figure 3, it is indicated that changes on amount of wood extractives, extracted by alcohol-benzene, hot-cold water solubility and $1 \% \mathrm{NaOH}$ solubility. The $1 \%$ of $\mathrm{NaOH}$ (mild alkaline) soluble value is important for determination of grade of wood decay (Kang et al., 2007). $1 \% \mathrm{NaOH}$ solubility of the beech chips dramatically increased with increasing $P$. ostreatus treatment time (Figure 3). Wood extractives are defined as a chemical compounds group which is soluble in various neutral solvents. In pulp and paper industry, wood extractives cause a lot of problems in the production process and also affect the paper properties such as the binding between fibers, and the water adsorption (Jansson and Nilvebrant, 2009). Solution of these problems are that the raw materials are waited nearly 6 weeks in storage area for mechanical pulping industries (Kırc1, 2003). In the Figure 3, Alcohol-benzene soluble values are decreased during the incubation time. Therefore, fungal treatments can be solved the problems caused by extractives and this 
storage time can be reduced and valuated with edible mushroom production.

Water soluble components of wood mainly consist of carbohydrates, proteins and inorganic materials (Fengel and Wegener, 1989). Hot and cold water solubility values are not regularly changed by incubation time. The main reason of this, increasing ash content (Figure 4) and fluctuation in protein content and amount of carbohydrates with incubation time.

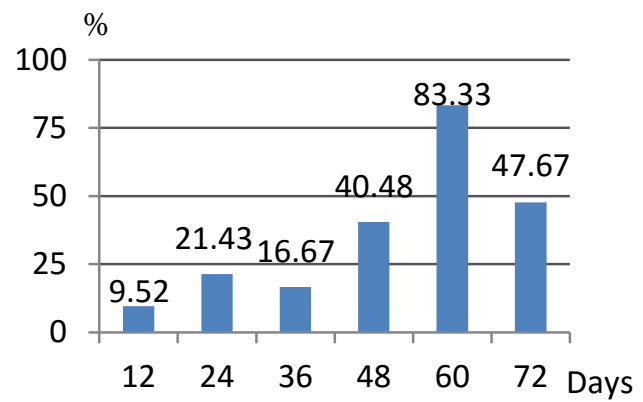

Figure 4. Changes in ash content ratios (\%)

Figure 4 shows a steady increase in ash content, excluding the last period. The highest change is $83.33 \%$ on 60 days. The reason of the increase of the ash content may be caused from the white rot fungi enzymes (ligninases), which are used by fungus for degrading lignin. Because ligninases contains metal ions or prosthetic groups (Teeri and Henriksson, 2009). Mushrooms needed more than more lignin degradation when it grow up and the ash content increasing with more and more ligninases enzyme production.

\section{Conclusion:}

Consequently, $P$. ostreatus will be usable for beech chips in mechanical pulping in terms of lignin degradation without much loss from amount of holocellulose and cellulose. Further researches are needed to determine the energy saving ratio and effects of $P$. ostreatus on beech wood fibers and fiberboards properties. These fungi should be studied for other wood species, used in Turkish fiberboard industry.

Because of the high nutrition value and protein content of $P$. ostreatus, it should be evaluated for some fiberboard plants as a pre-treating organism of wooden raw material.

\section{References}

Akhtar, M., Attridge, M. C., Myers, G. C., Kirk, T. K., Blanchette, R. A. 1992. Biomechanical pulping of loblolly pine with different strains of the white-rot fungus Ceriporiopsis subvermispora. Biomechan. Pulp, 2, 105-109.

Akhtar, M. 1994. Biomechanical pulping of aspen wood chips with three strains of Ceriporiopsis subvermispora. HolzforschungInternational Journal of the Biology, Chemistry, Physics and Technology of Wood, 48(3), 199202.

Akhtar, M., Scott, G. M., Swaney, R. E., \& Kirk, T. K. 1998. Overview of biomechanical and biochemical pulping research, Chapter 2. (Eds ERIKSSON, Karl-Erik L., and A., CAVACOPAULO, Enzyme Applications in Fiber Processing) American Chemical Society, Vol. 687, pp. 15-26, Washington DC.

Akhtar, M., Scott, G. M., Swaney, R. E., Shipley, D. F. 2000. Biomechanical pulping: a mill-scale evaluation. Resources, Conservation and Recycling, 28(3), 241-252.

Akgül, M., Çamlıbel, O., Gedik, T. 2013. Türkiye ve dünyadaki mdf endüstrisine genel bir bakış. Düzce Üniversitesi Ormancılık Dergisi, 9(2) 117-125.

Eroğlu, H., Usta M. 2000. LifLevha üretim teknolojisi, K.T.Ü. Orman Fakültesi Yayın No: 200/30, ISBN: 975-6983-10-8, KTU Matbaas1, Trabzon.

Fengel, D., Wegener, G. 1989. Wood: chemistry, ultrastructure, reactions. ISBN: 3-11012059-3, 613 p., Walter De Gruyter, New York.

Ferraz, A., Guerra, A., Mendonça, R., Masarin, F., Vicentim, M. P., Aguiar, A., Pavan, P. C. 2008. Technological advances and mechanistic basis for fungal biopulping. Enzyme and Microbial Technology, 43(2), 178-185.

Hua, J., Chen, G., Xu, D., Shi, S. Q. 2012. Impact of thermomechanical refining conditions on fiber quality and energy consumption by mill trial. BioResources, 7(2), 1919-1930.

Jansson, M. B., Nilvebrant, N. O. 2009. Wood extractives, Chapter 7. (Eds. EK M., G GELLERSTEDT G., and G. HENRIKSSON, Pulp and Paper Chemistry and Technology Volume 1 Wood Chemistry and Wood Biotechnology). Walter De Gruyter, pp. 147-171, Berlin.

Istek, A., Sivrikaya, H., Eroglu, H., Gulsoy, S. K. 2005. Biodegradation of Abies bornmülleriana (mattf.) and Fagus orientalis (1.) by the white rot fungus Phanerochaete chrysosporium. 
International Biodeterioration \& Biodegradation, 55(1), 63-67.

Kang, K. Y., Sung, J. S., Kim, D. Y. 2007. Evaluation of white-rot fungi for biopulping of wood. Mycobiology, 35(4), 205-209.

K1rc1, H. 2000. Kağit hamuru endüstrisi ders notlari, 274 s, Karadeniz Teknik Üniversitesi, Orman Fakültesi, Yayın No: 63, Trabzon

Malakani, M., Khademieslam, H., Hosseinihashemi, S. H., Zeninaly, F. 2014. Influence of fungal decay on chemi-mechanical properties of beech wood (Fagus orientalis). Cellul Chem Technol, 48(1-2), 97-103.

Myers, G. C., Leatham, G. F., Wegner, T. H., Blanchette, R. A. 1988. Fungal pretreatment of aspen chips improves strength of refiner mechanical pulp. Tappi J, 71(50), 105.

Nilsson, T. 2009. Biological wood degradation, Chapter 10. (Eds. EK M., G GELLERSTEDT G., and G. HENRIKSSON, Pulp and Paper Chemistry and Technology Volume 1 Wood Chemistry and Wood Biotechnology). Walter De Gruyter, pp. 219-249, Berlin.

TAPPI, 1988 a. Solvent extractives of wood and pulp. Test Method T 204 om-88.

TAPPI, 1988 b. Acid-insoluble lignin in wood and pulp. Test Method T 222 om-88.

TAPPI, 1993 a. Water solubility of wood and pulp. Test Method T 207 om-93.

TAPPI, 1993 b. One percent sodium hydroxide solubility of wood and pulp. Test Method T 212 om-93.

TAPPI, 1993 c. Alpha-, beta- and gamma cellulose in pulp. Test Method T 203 om-93.

TAPPI, 1993 d. Ash in wood, pulp, paper and paperboard: combustion at $525^{\circ} \mathrm{C}$ Test Method $\mathrm{T}$ 211 om-93.

Teeri, T., Henriksson, G. 2009. Enzymes degrading wood components, Chapter 11. (Eds. EK M., G GELLERSTEDT G., and G. HENRIKSSON, Pulp and Paper Chemistry and Technology Volume 1 Wood Chemistry and Wood Biotechnology). Walter De Gruyter, pp. 245-271, Berlin

Scott, G. M., Akhtar, M., Lentz, M. J., Horn, E., Swaney, R. E., Shipley, D. F. 1998. Incorporating biopulping technology into wood yard operations. TAPPI Pulping Conference (1998 October 25-29), 1313-1321, Montreal, Canada.

Singh, P., Sulaiman, O., Hashim, R., Rupani, P. F., Peng, L. C. 2010. Biopulping of lignocellulosic material using different fungal species: a review. Reviews in Environmental Science and Bio/Technology, 9(2), 141-151.

Ünal, S., Güney, K., Evcin, Ö., 2012. Kastamonu yöresinde ağaç mantari Pleurotus ostreatus (Jack.Ex.Fr.) Kum. (kayin mantari) yetiştiriciliği. Kastamonu'nun Doğal Zenginlikleri Sempozyumu (16 - 17 Ekim 2012), sf 141-146. Kastamonu, Türkiye.

Wise, L.E., Murphy, M., D'Addieco, A.A., 1946. Chlorite holocellulose, its fractionation and bearing on summative wood analysis and on studies on the hemicelluloses. Pap. Trade J. 122 (2), 35-43. 